\title{
PENGEMBANGAN BUKU INTISARI MATEMATIKA JENJANG SEKOLAH DASAR DITINJAU DARI ASPEK KELAYAKAN ISI, PENYAJIAN, BAHASA, DAN KEGRAFIKAN
}

\author{
Sri Rahayu ${ }^{1}$, Nur Fathonah ${ }^{2}$, Erlin Ladyawati ${ }^{3}$ \\ 1,2,3 Program Studi Pendidikan Matematika, Fakultas Keguruan dan Ilmu Pendidikan, Universitas PGRI Adi Buana \\ Surabaya \\ $\underline{\text { mamot92@gmail.com }}^{1}, \underline{\text { nurunipa@gmail.com }}^{2}, \underline{\text { erlin.evaluasi@gmail.com }}^{3}$
}

\begin{abstract}
Abstrak
Pada sebagian besar siswa, matematika merupakan pelajaran yang meninggalkan pengalaman yang kurang menyenangkan dalam belajar. Hal ini disebabkan oleh banyak faktor antara lain faktor siswa, guru, materi pelajaran, kurikulum dan lingkungan. Dari permasalahan yang diungkapkan di atas, hal yang perlu dilakukan untuk memecahkan masalah tersebut adalah mengembangkan buku intisari yang sesuai sehingga dapat meningkatkan komponen penting dalam mengembangkan kemampuan analitis dan kemampuan kritis peserta didik. Tujuan penelitian ini adalah mengembangkan buku intisari matematika ditinjau dari aspek kelayakan isi, penyajian, bahasa, dan kegrafikan. Penelitian ini merupakan penelitian pengembangan. Buku intisari Matematika jenjang sekolah dasar dikembangkan dengan model ADDIE (Analysis, Design, Development, Implementation, Evaluation). Adapun tahap-tahap pada model pengembangan model ADDIE antara lain tahap analysis meliputi: a. analisis kurikulum, b. analisis materi, dan c. analisis karakter siswa; tahap design meliputi: a. perancangan garis besar isi buku, b. menyusun peta kebutuhan buku, c. Menyusun instrumen penelitian; tahap development meliputi: a. penulisan buku, b. validasi buku, c. uji coba terbatas, d. revisi buku; tahap implementation dan tahap evalution. Dua tahap terakhir belum dilakukan mengingat keterbatasan waktu penelitian. Buku ini mendapatkan validasi kelayakan isi, penyajian, bahasa, dan kegrafikan dengan kriteria sangat baik, dan dapat digunakan dengan revisi. Dengan beberapa revisi, maka buku ini sudah dapat digunakan dalam implementasi di sekolah. Setelah diimplementasikan di sekolah buku Intisari Matematika jenjang Sekolah, diperoleh nilai ketuntasan siswa yaitu secara klasikal kelas dikatakan tuntas dengan pembelajaran menggunakan buku Intisari Matematika.
\end{abstract}

Kata Kunci: buku intisari matematika, kelayakan isi, kelayakan penyajian, kelayakan bahasa, kelayakan kegrafikan

\section{PENDAHULUAN}

Pada sebagian besar siswa, matematika merupakan pelajaran yang meninggalkan pengalaman yang kurang menyenangkan dalam belajar. Pengalaman belajar yang membekas selama belajar akan mempengaruhi sikap siswa terhadap matematika. Sikap siswa terhadap matematika akan positif jika pengalaman belajar yang diterima siswa selama belajar menyenangkan dan sebaliknya jika pengalaman belajar yang diterima kurang menyenangkan maka sikap positif siswa terhadap pelajaran matematika akan terhambat. Kenyataan dilapangan menunjukkan bahwa sebagian besar siswa terutama siswa sekolah dasar menemui pengalaman yang kurang menyenangkan selama belajar matematika. Hal ini disebabkan oleh banyak faktor antara lain faktor siswa, guru, materi pelajaran, kurikulum dan lingkungan.

Berbicara tentang mata pelajaran terutama matematika, penguasaan matematika sejak dini, hal ini sedang berada dalam sebuah masalah. Pada sekolah dasar peserta didik kesulitan memahami konsep matematika, sehingga pada jenjang yang lebih tinggi peserta didik pun kesulitan memahami konsep matematika yang berakibat pada pencapaian hasil pembelajaran yang rendah.

Dari permasalahan yang diungkapkan di atas, hal yang perlu dilakukan untuk memecahkan masalah tersebut adalah mengembangkan modul intisari beserta media pembelajaran yang sesuai sehingga dapat meningkatkan komponen penting dalam mengembangkan kemampuan analitis dan kemampuan kritis peserta didik. Oleh karena itu dalam penelitian ini, peneliti mengambil judul penelitian "Pengembangan Buku Intisari Matematika Jenjang Sekolah Dasar Ditinjau Dari Aspek Kelayakan Isi, Penyajian, Bahasa, Dan Kegrafikan”.

\section{METODE}

\section{Jenis Penelitian}

Penelitian ini merupakan jenis penelitian pengembangan, yaitu penelitian yang mengembangkan suatu produk. Produk yang dihasilkan dalam penelitian ini adalah suatu produk. Produk yang dihasilkan dalam penelitian ini adalah buku intisari matematika. Model pengembangan yang digunakan dalam penelitian ini 
adalah model pengembangan ADDIE, yaitu Analysis (analisis), Design (desain), Development (pengembangan), Implementation (implementasi), Evaluation (evaluasi) (Benny, 2009).

\section{Prosedur Pengembangan}

Pengembangan buku intisari mengikuti lima tahapan model pengembangan ADDIE, yaitu tahap analysis, design, development, implementation dan evaluation. Dalam penelitian ini tahap implementation dan evaluation belum bisa diterapkan karena keterbatasan waktu penelitian. Penjelasannya sebagai berikut:

1. Tahap Analisis (Analysis)

Desain tahap analisis berfokus pada target audiens. Pada tahap analisis, dilakukan pendefinisian permasalahan instruksional, tujuan instruksional, sasaran pembelajaran serta dilakukan identifikasi lingkungan pembelajaran dan pengetahuan yang dimiliki oleh siswa. Secara garis besar pada tahap analisis dibagi menjadi dua, yaitu analisis kurikulum dan analisis kebutuhan. Berikut penjelasannya:

a. Analisis kurikulum yang digunakan meliputi analisis mengenai kompetensi yang akan diajarkan kepada siswa. Analisis kurikulum dilakukan dengan menganalisis kompetensi yang ada pada kurikulum untuk memahami kedalaman dan keluasan kompetensi yang harus dikembangkan dengan bentuk materi.

b. Analisis kebutuhan dan karakteristik siswa. Analisis kebutuhan dan karakteristik siswa dilakukan dengan mencari informasi mengenai siswa secara khusus dengan wawancara dengan guru.

2. Tahap Desain (Design)

Pada tahap perancangan desain berdasarkan perihal yang diperoleh pada tahap analisis. Tahap desain meliputi:

a. Menentukan garis besar dari materi yang akan dikembangkan. Materi ditentukan berdasarkan analisis kurikulum dan kebutuhan siswa, selanjutnya dideskripsikan pokok-pokok dari materi tersebut agar sesuai dengan tingkat keluasan dan kedalaman kompetensi yang akan diajarkan pada siswa.

b. Merancang desain buku. Melakukan rancangan desain buku intisari berupa menetapkan unsurunsur yang ada pada buku intisari sebagai berikut:

1) Bagian pendahuluan, terdiri dari:
a) Cover;

b) Halaman motivasi;

c) Kata pengantar;

d) Daftar isi.

2) Bagian isi, terdiri dari:
a) Materi;
b) Latihan-latihan.

3) Bagian penutup, terdiri dari:

a) Jawaban latihan terpilih;

b) Indeks;

c) Daftar pustaka

3. Tahap Pengembangan (Development)

Pada tahap pengembangan, dilakukan pembuatan dan penggabungan konten yang sudah dirancang pada tahap desain. Setelah buku intisari matematika dinyatakan layak untuk divalidasi, selanjutnya buku divalidasi oleh ahli materi dan ahli media untuk mendapatkan kelayakan. Ahli materi untuk memvalidasi kelayakan isi, kelayakan penyajian, dan kelayakan bahasa. Sedangkan ahli media untuk memvalidasi kelayakan kegrafikan.

\section{Jenis Data}

Jenis data pada penelitian pengembangan ini ada adalah data kuantitatif. Data kuantitatif diperoleh berdasarkan hasil validasi kelayakan. Validator untuk validasi kelayakan ada dua yaitu ahli materi dan ahli media. Ahli materi adalah salah satu dosen Program Studi Pendidikan Matematika Universitas PGRI Adi Buana Surabaya, dan satu guru sekolah dasar.

\section{Instrumen Penelitian}

Instrumen yang digunakan dalam penelitian adalah lembar validasi kelayakan buku intisari oleh ahli materi dan ahli media. Penilaian yang digunakan pada instrumen penilaian dalam bentuk skala Likert dengan 4 alternatif jawaban.

\section{Analisis Data}

Data kuantitatif dianalisis menurut aspek kelayakan buku yang selanjutnya dihitung rata-rata skor dari setiap aspek. Sumber data kuantitatif aspek kelayakan berasal dari empat komponen untuk buku intisari yaitu komponen kelayakan isi, kelayakan penyajian, kelayakan bahasa, dan kelayakan kegrafikan.

Penjelasan aturan penilaian untuk lembar validasi kelayakan buku oleh ahli materi dan ahli media adalah sebagai berikut: 
Tabel 1. Aturan Penilaian Validasi Kelayakan Buku oleh Ahli Materi dan Ahli Media

\begin{tabular}{cc}
\hline Jawaban & Skor Pernyataan Positif \\
\hline Sangat Baik (SB) & 4 \\
Baik (B) & 3 \\
Kurang Baik (KB) & 2 \\
\hline Sangat Kurang Baik (SKB) & 1 \\
\hline \hline
\end{tabular}

Penjelasan analisis data untuk validasi kelayakan buku adalah sebagai berikut:

1. Menghitung rata-rata skor dari setiap kriteria penilaian dengan rumus:

$$
\bar{X}=\frac{\sum x}{n}
$$

Keterangan:

$\bar{X} \quad=$ Skor rata-rata seluruh aspek

$\sum x=$ Jumlah skor seluruh aspek.

$\mathrm{n} \quad=$ Banyaknya butir pernyataan

2. Penentuan Kriteria Kelayakan Buku sebagai berikut:

Tabel 2. Kriteria Penetapan Kualitas

\begin{tabular}{cc}
\hline Rentang Nilai & Kriteria \\
$3,3-4,0$ & Sangat Baik \\
$2,6-3,2$ & Baik \\
$1,8-2,5$ & Kurang Baik \\
$1,0-1,7$ & Tidak Baik \\
\hline \hline
\end{tabular}

penyajian, dan bahasa. Validator ahli materi ini ada dua

\section{HASIL DAN PEMBAHASAN}

\section{Penyajian Data}

Berikut disajikan data tentang validasi kelayakan buku intisari matematika jenjang sekolah dasar oleh ahli materi. Ahli materi memvalidasi tentang kelayakan isi, orang dosen Program Studi Pendidikan Guru Sekolah Dasar konsentrasi Matematika di Universitas PGRI Adi Buana Surabaya dan guru mata pelajaran Matematika di Sekolah Dasar Muhammadiyah 15 Surabaya.

Tabel 3. Hasil Validasi Buku Intisari Matematika Jenjang Sekolah Dasar oleh Ahli Materi

\begin{tabular}{|c|c|c|c|}
\hline \multirow{2}{*}{ Indikator Penilaian } & \multirow{2}{*}{ Butir Penilaian } & \multicolumn{2}{|c|}{ Validator } \\
\hline & & V1 & $\mathbf{V} 2$ \\
\hline \multicolumn{4}{|l|}{ 1. Aspek Kelayakan Isi } \\
\hline \multirow[t]{2}{*}{ A. Kesesuaian Materi dengan KD } & 1. Kelengkapan materi & 4 & 4 \\
\hline & 2. Keluasan Materi & 4 & 4 \\
\hline & 3. Kedalaman Materi & 4 & 4 \\
\hline \multirow{5}{*}{ B. Keakuratan Materi } & 4. Keakuratan konsep dan definisi & 4 & 4 \\
\hline & 5. Keakuratan data dan fakta & 4 & 4 \\
\hline & 6. Keakuratan contoh dan kasus & 3 & 4 \\
\hline & $\begin{array}{l}\text { 7. Keakuratan gambar, diagram, } \\
\text { dan ilustrasi }\end{array}$ & 4 & 4 \\
\hline & 8. Keakuratan istilah-istilah & 3 & 4 \\
\hline \multirow[t]{2}{*}{ C. Kemutakhiran Materi } & $\begin{array}{l}\text { 9. Gambar, diagram, dan ilustrasi } \\
\text { dalam kehidupan sehari-hari }\end{array}$ & 4 & 4 \\
\hline & $\begin{array}{l}\text { 10. Menggunakan contoh dan kasus } \\
\text { yang terdapat dalam kehidupan } \\
\text { sehari-hari }\end{array}$ & 4 & 4 \\
\hline \multirow[t]{2}{*}{ D. Mendorong Keingintahuan } & 11. Mendorong rasa ingin tahu & 4 & 4 \\
\hline & $\begin{array}{l}\text { 12. Menciptakan } \\
\text { bertanya }\end{array}$ & 4 & 4 \\
\hline \multicolumn{4}{|l|}{ 2. Aspek Kelayakan Penyajian } \\
\hline \multirow[t]{3}{*}{ F. Pendukung Penyajian } & $\begin{array}{l}\text { 14. Contoh-contoh soal dalam } \\
\text { setiap kegiatan belajar }\end{array}$ & 4 & 4 \\
\hline & $\begin{array}{l}\text { 15. Soal latihan setiap akhir } \\
\text { kegiatan pembelajaran }\end{array}$ & 4 & 4 \\
\hline & 16. Kunci jawaban soal latihan & 4 & 4 \\
\hline
\end{tabular}


Sri Rahayu ${ }^{1}$, Nur Fathonah ${ }^{2}$, Erlin Ladyawati³: Pengembangan Buku Intisari Matematika Jenjang Sekolah Dasar Ditinjau dari Aspek Kelayakan Isi, Penyajian, Bahasa, dan Kegrafikan

\begin{tabular}{|c|c|c|c|}
\hline \multirow[t]{2}{*}{ Indikator Penilaian } & \multirow[t]{2}{*}{ Butir Penilaian } & \multicolumn{2}{|c|}{ Validator } \\
\hline & & V1 & V2 \\
\hline & 17. Pengantar & 4 & 4 \\
\hline & 18. Glosarium & 3 & 4 \\
\hline & 19. Daftar pustaka & 4 & 3 \\
\hline G. Penyajian Pembelajaran & 20. Keterlibatan peserta didik & 4 & 4 \\
\hline H. Koherensi dan Keruntutan Alur Pikir & $\begin{array}{l}\text { 21. Keutuhan makna dalam } \\
\text { kegiatan belajar }\end{array}$ & 3 & 3 \\
\hline \multicolumn{4}{|l|}{ Aspek Kelayakan Bahasa } \\
\hline I. Lugas & 22. Ketepatan struktur kalimat & 4 & 4 \\
\hline & 23. Keefektifan kalimat & 4 & 3 \\
\hline & 24. Kebakuan istilah & 3 & 4 \\
\hline J. Komunikatif & $\begin{array}{l}\text { 25. Pemahaman terhadap pesan } \\
\text { atau informasi }\end{array}$ & 4 & 4 \\
\hline K. Dialogis dan Interaktif & $\begin{array}{l}\text { 26. Kemampuan memotivasi } \\
\text { peserta didik }\end{array}$ & 4 & 4 \\
\hline $\begin{array}{l}\text { L. Kesesuaian dengan Perkembangan Peserta } \\
\text { Didik }\end{array}$ & $\begin{array}{l}\text { 27. Kesesuaian } \\
\text { perkembangan } \\
\text { peserta didik }\end{array}$ & 4 & 4 \\
\hline & $\begin{array}{l}\text { 28. Kesesuaian dengan tingkat } \\
\text { perkembangan emosional } \\
\text { peserta didik }\end{array}$ & 4 & 4 \\
\hline M. Kesesuaian dengan Kaidah Bahasa & 29. Ketepatan tata bahasa & 4 & 4 \\
\hline & 30. Ketepatan ejaan & 4 & 4 \\
\hline
\end{tabular}

Tabel 4. Hasil Validasi Buku Intisari Matematika Jenjang Sekolah Dasar oleh Ahli Media

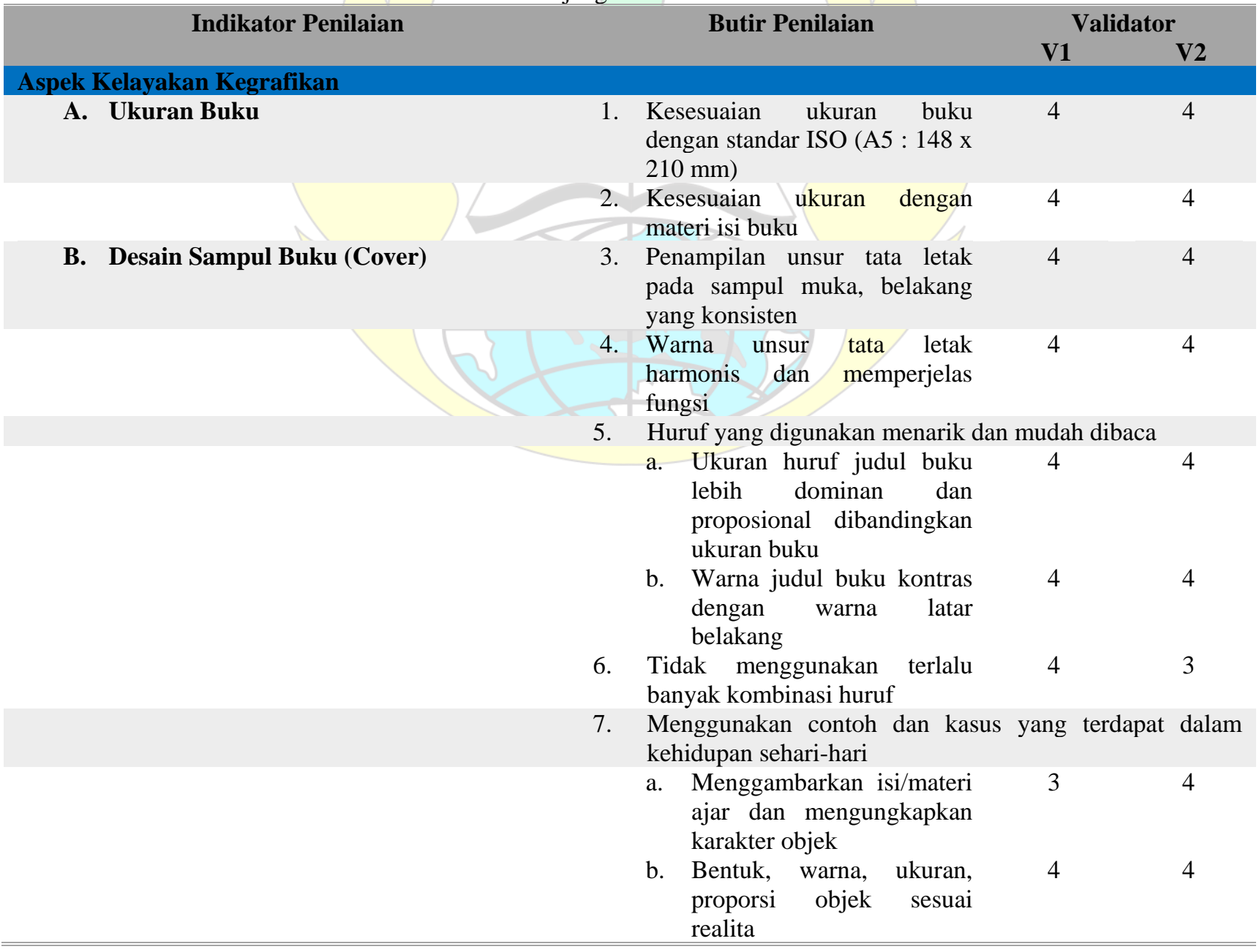




\section{Indikator Penilaian}

C. Desain Isi Buku

\section{Butir Penilaian}

V2

8. Konsistensi tata letak

\begin{tabular}{|c|c|c|}
\hline a. & $\begin{array}{l}\text { Penempatan unsur tata } \\
\text { letak konsisten berdasarkan } \\
\text { pola }\end{array}$ & 4 \\
\hline & $\begin{array}{l}\text { Pemisahan antar paragraf } \\
\text { jelas }\end{array}$ & 4 \\
\hline
\end{tabular}

9. Unsur tata letak harmonis

a. Bidang cetak dan marjin
proposional
b. Spasi antar teks dan
ilustrasi sesuai

10. Unsur tata letak lengkap

$\begin{array}{llll}\text { a. Judul dan subjudul materi } & 4 & 4 \\ \text { b. Ilustrasi dan keterangan } & 4 & 4 \\ \text { gambar } & \end{array}$

11. Tata letak mempercepat halaman

a. Penempatan latar belakang tidak menganggu judul, teks, angka halaman

b. Penempatan judul, subjudul, ilustrasi, dan keterangan gambar tidak menganggu pemahaman

3

4

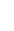
Tipografi isi buku sederhana

a. Tidak menggunakan terlalu banyak jenis huruf

b. Penggunaan variasi huru (bold, italic, all capital, small capital) tidak berlebihan

c. Lebar susunan teks normal 4

d. Spasi antar baris susunan $4 \quad 4$ teks normal

e. Spasi antar huruf normal

13. Topografi isi buku memudahkan pemahaman

a. Jenjang buku jelas, 4 4 konsisten, dan proposional

b. Tanda potongan kata $\quad 3 \quad 4$

14. Ilustrasi isi
a. Mampu mengungkapkan makna/arti dari objek
b. Bentuk akurat dan proposional sesuai dengan kenyataan
c. Kreatif dan dinamis

$\begin{array}{ll}4 & 4 \\ 4 & 4 \\ 4 & 4\end{array}$

kelayakan penyajian, kelayakan bahasa. 
Tabel 5. Rekap Hasil Validasi Kelayakan Buku Intisari Matematika Jenjang Sekolah Dasar oleh Ahli Materi

\begin{tabular}{|c|c|c|c|c|c|}
\hline \multirow{2}{*}{ Indikator Penilaian } & \multirow{2}{*}{ Butir Penilaian } & \multicolumn{3}{|c|}{ Validator } & \multirow{2}{*}{$\mathbf{R}_{\mathbf{1}}$} \\
\hline & & $\mathbf{V}_{1}$ & $\mathbf{V}_{2}$ & $\bar{X}$ & \\
\hline \multicolumn{6}{|c|}{ 1. ASPEK KELAYAKAN ISI } \\
\hline \multirow{8}{*}{$\begin{array}{l}\text { A. Kesesuaian } \\
\text { Materi den } \\
\text { KD } \\
\text { B. Keakuratan } \\
\text { Materi }\end{array}$} & 1. Kelengkapan materi & 4 & 4 & 4 & \multirow{12}{*}{3,9} \\
\hline & 2. Keluasan Materi & 4 & 4 & 4 & \\
\hline & 3. Kedalaman Materi & 4 & 4 & 4 & \\
\hline & 4. Keakuratan konsep dan definisi & 4 & 4 & 4 & \\
\hline & 5. Keakuratan data dan fakta & 4 & 4 & 4 & \\
\hline & 6. Keakuratan contoh dan kasus & 3 & 4 & 3,5 & \\
\hline & $\begin{array}{l}\text { 7. Keakuratan gambar, diagram, dan } \\
\text { ilustrasi }\end{array}$ & 4 & 4 & 4 & \\
\hline & 8. Keakuratan istilah-istilah & 3 & 4 & 3,5 & \\
\hline \multirow[t]{2}{*}{$\begin{array}{l}\text { C. Kemutakhiran } \\
\text { Materi }\end{array}$} & $\begin{array}{l}\text { 9. Gambar, diagram, dan ilustrasi dalam } \\
\text { kehidupan sehari-hari }\end{array}$ & 4 & 4 & 4 & \\
\hline & $\begin{array}{l}\text { 10. Menggunakan contoh dan kasus yang } \\
\text { terdapat dalam kehidupan sehari-hari }\end{array}$ & 4 & 4 & 4 & \\
\hline \multirow{2}{*}{$\begin{array}{l}\text { D. Mendorong } \\
\text { Keingintahuan }\end{array}$} & 11. Mendorong rasa ingin tahu & 4 & 4 & 4 & \\
\hline & 12. Menciptakan kemampuan bertanya & 4 & 4 & 4 & \\
\hline \multicolumn{6}{|c|}{ ASPEK KELAYAKAN PENYAJIAN } \\
\hline E. Teknik Penyajian & 13. Keruntutan konsep & 4 & 4 & 4 & \multirow{10}{*}{3,8} \\
\hline \multirow[t]{6}{*}{$\begin{array}{l}\text { F. Pendukung } \\
\text { Penyajian }\end{array}$} & $\begin{array}{l}\text { 14. Contoh-contoh soal dalam setiap } \\
\text { kegiatan belajar }\end{array}$ & 4 & 4 & 4 & \\
\hline & $\begin{array}{l}\text { 15. Soal latihan setiap akhir kegiatan } \\
\text { pembelajaran }\end{array}$ & 4 & 4 & 4 & \\
\hline & 16. Kunci jawaban soal latihan & 4 & 4 & 4 & \\
\hline & 17. Pengantar & 4 & 4 & 4 & \\
\hline & 18. Glosarium & 3 & 4 & 3,5 & \\
\hline & 19. Daftar pustaka & 4 & 3 & 4 & \\
\hline \multirow{2}{*}{$\begin{array}{l}\text { G. Penyajian } \\
\text { Pembelajaran }\end{array}$} & 20. Keterlibatan peserta didik & 4 & 4 & \multirow[t]{2}{*}{4} & \\
\hline & & & & & \\
\hline $\begin{array}{l}\text { H. Koherensi dan } \\
\text { Keruntutan Alur } \\
\text { Pikir }\end{array}$ & $\begin{array}{l}\text { 21. Keutuhan makna dalam kegiatan } \\
\text { belajar }\end{array}$ & 3 & 3 & 3 & \\
\hline \multicolumn{6}{|c|}{ ASPEK KELAYAKAN BAHASA } \\
\hline \multirow[t]{3}{*}{ I. Lugas } & 22. Ketepatan struktur kalimat & 4 & 4 & 4 & \multirow{9}{*}{3,9} \\
\hline & 23. Keefektifan kalimat & 4 & 3 & 3,5 & \\
\hline & 24. Kebakuan istilah & 3 & 4 & 3,5 & \\
\hline J. Komunikatif & $\begin{array}{l}\text { 25. Pemahaman terhadap pesan atau } \\
\text { informasi }\end{array}$ & 4 & 4 & 4 & \\
\hline $\begin{array}{l}\text { K. Dialogis } \\
\text { Interaktif }\end{array}$ & 26. Kemampuan memotivasi peserta didik & 4 & 4 & 4 & \\
\hline \multirow[t]{2}{*}{$\begin{array}{l}\text { L. Kesesuaian } \\
\text { dengan } \\
\text { Perkembangan } \\
\text { Peserta Didik }\end{array}$} & $\begin{array}{l}\text { 27. Kesesuaian dengan perkembangan } \\
\text { intelektual peserta didik }\end{array}$ & 4 & 4 & 4 & \\
\hline & $\begin{array}{l}\text { 28. Kesesuaian dengan tingkat } \\
\text { perkembangan emosional peserta didik }\end{array}$ & 4 & 4 & 4 & \\
\hline \multirow{2}{*}{$\begin{array}{l}\text { M. Kesesuaian } \\
\text { dengan Kaidah } \\
\text { Bahasa }\end{array}$} & 29. Ketepatan tata bahasa & 4 & 4 & 4 & \\
\hline & 30. Ketepatan ejaan & & & & \\
\hline
\end{tabular}

Berikut akan disajikan tabel rekap hasil validasi jenjang Sekolah Dasar untuk aspek kelayakan kegrafikan. kelayakan pengembangan buku intisari matematika 
Tabel 6. Rekap Hasil Validasi Kelayakan Kuantitatif Buku Intisari Matematika Jenjang Sekolah Dasar oleh Ahli Media

\begin{tabular}{|c|c|c|c|c|c|}
\hline \multirow{2}{*}{ Indikator Penilaian } & \multirow{2}{*}{ Butir Penilaian } & \multicolumn{3}{|c|}{ Validator } & \multirow{2}{*}{$\mathbf{R}_{1}$} \\
\hline & & $\mathbf{V}_{1}$ & $\mathbf{V}_{1}$ & $\bar{X}$ & \\
\hline
\end{tabular}

A. Ukuran Buku

B. Desain Sampul Buku 3. Penampilan unsur tata letak pada (Cover)

\section{Desain Isi Buku}

1. Kesesuaian ukuran buku dengan standar ISO (A5 : 148 x $210 \mathrm{~mm}$ )

2. Kesesuaian ukuran dengan materi is buku sampul muka, belakang yang konsisten

4. Warna unsur tata letak harmonis dan memperjelas fungsi

5. Huruf yang digunakan menarik dan mudah dibaca

a. Ukuran huruf judul buku lebih dominan dan proposional dibandingkan ukuran buku

b. Warna judul buku kontras dengan warna latar belakang

6. Tidak menggunakan terlalu banyak kombinasi huruf

7. Ilustrasi sampul buku

a. Menggambarkan isi/materi ajar dan mengungkapkan karakter objek

b. Bentuk, warna, ukuran, proporsi objek sesuai realita

8. Konsistensi tata letak

a. Penempatan unsur tata letak konsisten berdasarkan pola

b. Pemisahan antar paragraf jelas

4

$\begin{array}{lll}4 & 4 & 4\end{array}$

$\begin{array}{lll}4 & 4 & 4\end{array}$

$4 \quad 4 \quad 4$

4

Unsur tata letak harmonis

a. Bidang cetak dan marjin proposional

b. Spasi antar teks dan ilustrasi sesuai

10. Unsur tata letak lengkap

a. Judul dan subjudul materi

b. Ilustrasi dan keterangan gambar

11. Tata letak mempercepat halaman
a. Penempatan hiasan/ilustrasi sebagai latar belakang tidak menganggu judul, teks, angka halaman
b. Penempatan judul, subjudul, ilustrasi, dan keterangan gambar tidak menganggu pemahaman

$4 \quad 4$
4

$3 \quad 3,5$

12. Tipografi isi buku sederhana
a. Tidak menggunakan terlalu banyak jenis huruf
b. Penggunaan variasi huruf (bold, italic, all capital, small capital) tidak berlebihan
c. Lebar susunan teks normal
d. Spasi antar baris susunan teks normal
e. Spasi antar huruf normal
Topografi isi buku memudahkan pemahaman
a. Jenjang buku jelas, konsisten, dan

$\begin{array}{ll}4 & 4 \\ 4 & 4 \\ & \\ 4 & 4 \\ 4 & 4 \\ 4 & 3,5\end{array}$

$4 \quad 4$

$4 \quad 4$




\begin{tabular}{|c|c|c|c|c|c|}
\hline \multirow{2}{*}{ Indikator Penilaian } & \multirow{2}{*}{ Butir Penilaian } & \multicolumn{3}{|c|}{ Validator } & \multirow{2}{*}{$\mathbf{R}_{1}$} \\
\hline & & $\mathbf{V}_{1}$ & $\mathbf{V}_{1}$ & $\bar{X}$ & \\
\hline & $\begin{array}{l}\text { proposional } \\
\text { b. Tanda potongan kata }\end{array}$ & & 4 & 3,5 & \\
\hline & $\begin{array}{l}\text { 14. Ilustrasi isi } \\
\text { a. Mampu mengungkapkan } \\
\text { makna/arti dari objek }\end{array}$ & & 4 & 4 & \\
\hline & $\begin{array}{l}\text { b. Bentuk akurat dan proposional } \\
\text { sesuai dengan kenyataan }\end{array}$ & & 4 & 4 & \\
\hline & c. Kreatif dan dinamis & & 4 & 4 & \\
\hline
\end{tabular}

Dari hasil kedua tabel diatas dapat dinilai secara kualitatif tentang kelayakan buku intisari matematika jenjang sekolah dasar.

Tabel 7. Penentuan Kriteria Buku Intisari Matematika Jenjang Sekolah Dasar

\begin{tabular}{ccc} 
Aspek & $\mathbf{R}_{\mathbf{1}}$ & Kriteria \\
\hline Aspek Kelayakan Isi & 3,9 & Sangat Baik \\
Aspek Kelayakan Penyajian & 3,8 & Sangat Baik \\
Aspek Kelayakan Bahasa & 3,9 & Sangat Baik \\
Aspek Kelayakan Kegrafikan & 3,6 & Sangat Baik \\
\hline \hline
\end{tabular}

\section{Pembahasan}

Penelitian ini menggunakan model/pengembangan ADDIE , yaitu Analysis/Analisis, Design/Desain, Development/Pengembangan, Implementation/ Implementasi, Evaluation/ Evaluasi. Berikut tahap yang sudah dilalui.

1. Tahap Analisis (Analysis)

Pada tahap analisis, kegiatan yang dilakukukan adalah analisis kurikulum, dan analisis kebutuhan dan karakteristik siswa. Untuk kegiatan analisis kurikulum yaitu mengalisis kompetensi yang ada pada kurikulum untuk memahami kedalaman dan keluasan kompetensi yang harus dikembangkan dengan bentuk materi. Analisis kurikulum dilaksanakan peneliti bekerjasama dengan guru mata pelajaran Matematika atau guru kelas VI. Analisis kebutuhan dan karakteristik siswa dilakukan dengan mencari informasi mengenai siswa secara umum dengan memperhatikan pendapat ahli serta mencari informasi mengenai siswa secara khusus dengan wawancara dengan guru.

2. Tahap Desain (Design)

Pada tahap perancangan desain kegiatan yang telah dilakukan meliputi :

a. Menentukan garis besar dari materi yang akan dikembangkan

Materi ditentukan berdasarkan analisis kurikulum dan kebutuhan siswa, selanjutnya peneliti menyusun pokok-pokok materi dari jenjang kelas 1 sampai dengan kelas 6 Sekolah Dasar agar sesuai dengan tingkat keluasan dan kedalaman kompetensi yang akan diajarkan pada siswa.

b. Merancang desain buku

Melakukan rancangan desain buku intisari. Hal ini dilakukan supaya buku terlihat menarik, mudah dipahami, dan tidak banyak revisi pada validator

3. Tahap Pengembangan (Development)

Pada tahap pengembangan, kegiatan yang telah dilakukan adalah pembuatan dan penggabungan konten yang sudah dirancang pada tahap desain. Pada pembuatan buku intisari dan buku media pembelajaran matematika, peneliti selalu melakukan revisi. Setelah buku intisari matematika dinyatakan layak untuk divalidasi, selanjutnya buku divalidasi oleh ahli materi dan ahli media untuk mendapatkan kelayakan Dari hasil validasi kelayakan buku intisari diperoleh hasil kriteria dari kelayakan isi, penyajian, bahasa, dan kegrafikan bahwa buku ini sangat baik. Harapan kedua validator adalah buku ini bisa diterbitkan secara luas karena buku ini adalah satusatunya (menurut saya) buku yang menyajikan materi dari kelas 1 sampai kelas 6 jenjang Sekolah Dasar dan bisa menjadi buku pendamping dalam pembelajaran.

\section{PENUTUP}

\section{Simpulan}

Berdasarkan kegiatan yang telah dilakukan maka dapat ditarik kesimpulan yaitu dihasilkan buku dengan judul "Intisari Matematika jenjang Sekolah Dasar" dengan perolehan kelayakan dengan kriteria: 
1. Buku Intisari Matematika jenjang Sekolah Dasar mendapatkan kelayakan isi dengan kriteria "sangat baik".

2. Buku Intisari Matematika jenjang Sekolah Dasar mendapatkan kelayakan penyajian dengan kriteria "sangat baik".

3. Buku Intisari Matematika jenjang Sekolah Dasar mendapatkan kelayakan bahasa dengan kriteria "sangat baik".

4. Buku Intisari Matematika jenjang Sekolah Dasar mendapatkan kelayakan kegrafikan dengan kriteria "sangat baik".

\section{DAFTAR PUSTAKA}

Arikunto, Suharsimi. 2009. Dasar-Dasar Evaluasi Pendidikan. Jakarta: Bumi Aksara.

Azhar, Arsyad. (2011). Media Pembelajaran. Jakarta: PT Raja Grafindo Persada.

Benny, A. Pribadi. (2009). Model Desain Sistem Pembelajaran. Jakarta: PT Dian Rakyat.
Chatib, Munif. 2012. Sekolahnya Manusia: Sekolah Berbasis Multiple Intelligences di Indonesia. Bandung: Mizan Media Utama.

Supriadi, Dedi. (2000). Anatomi Buku Sekolah di Indonesia: Problematika Penilaian, Pentebaran dan Penggunaan Buku Pelajaran, Buku Bacaan dan Buku Sumber. Yogyakarta: Adicipta.

Depdiknas. (2008). Panduan Pengembangan Bahan Ajar. Jakarta: Direktorat Pembinaan Sekolah Menengah Atas, Dirjen Manajemen Pendidikan Dasar dan Menengah, Depdinas.

Hudojo, Herman. (1988). Mengajar Belajar Matematika. Jakarta: Direktorat Jenderal Pendidikan Tinggi

Suherman, Erman, dkk. (2003). Strategi Pembelajaran Matematika Kontemporer. Bandung: UPI.

Uno, Hamzah B. (2008). Perencanaan Pembelajaran. Jakarta: PT Bumi Aksara..

Yamin, Martinis dan Bansu I. Ansari. (2009). Taktik Mengembangkan Kemampuan Individu

Siswa. Jakarta: Gaung Persada Press

Woolfolk, Anita. (2009). Educatiacation Psychology: Active Learning Edition, Terj.Helly Prajitno Soetjipto dan Sri Mulyantini Soetjipto. Yogyakarta: Pustaka Pelajar. 
Sri Rahayu ${ }^{1}$, Nur Fathonah ${ }^{2}$, Erlin Ladyawati³: Pengembangan Buku Intisari Matematika Jenjang Sekolah Dasar Ditinjau dari Aspek Kelayakan Isi, Penyajian, Bahasa, dan Kegrafikan

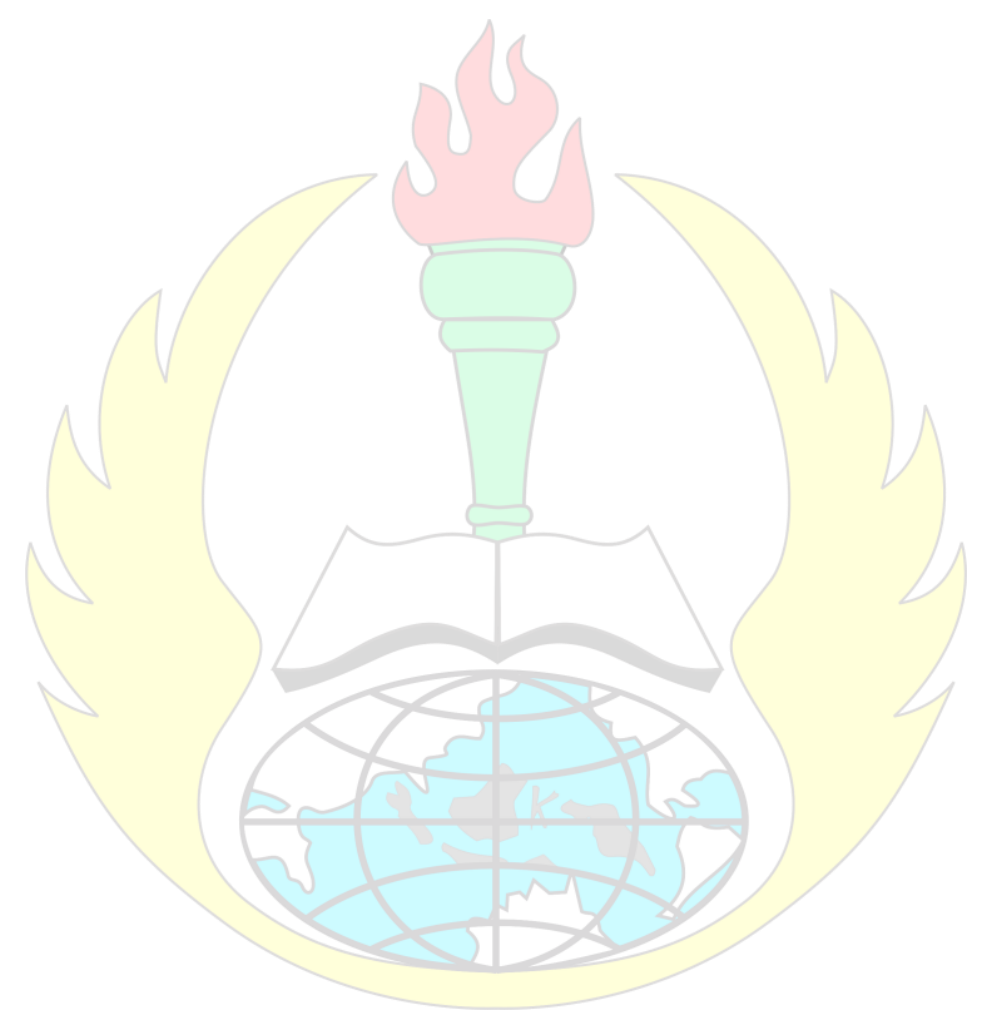

